\title{
Summer diapause and winter quiescence of Hippodamia (Semiadalia) undecimnotata (Coleoptera: Coccinellidae) in central Greece
}

\author{
Panayotis KATSOYANNOS ${ }^{1}$, Dimitris C. KONTODIMAS ${ }^{2 *}$ and George STATHAS ${ }^{3}$ \\ ${ }^{1}$ National Agricultural Research Foundation, 19 Eghialias \& Halepa, 15125 Marousi, Greece \\ ${ }^{2}$ Benaki Phytopathological Institute, 8 St. Delta, 14561 Kifissia, Greece \\ ${ }^{3}$ Technological Educational Institute of Kalamata, Dept. of Crop Production, 24100 Antikalamos, Greece
}

Key words. Coccinellidae, Hippodamia (Semiadalia) undecimnotata, diapause, quiescence, aestivo-hibernation

\begin{abstract}
The aestivo-hibernation in central Greece of the aphidophagous ladybeetle Hippodamia (Semiadalia) undecimnotata (Schneider) (Coleoptera: Coccinellidae) was studied. H. undecimnotata is a multivoltine species in Greece. In the lowlands, all instars are abundant in spring, becoming scarce from July until the end of October and they are absent in winter. In June, most $H$. undecimnotata adults migrate to mountainous aestivo-hibernation sites. The duration of pre-oviposition period in females sampled monthly from the summits of the mountains Chlomo and Kitheron in central Greece and transferred to laboratory conditions of high temperature $\left(25^{\circ} \mathrm{C}\right)$, long day $(16 \mathrm{~L}: 8 \mathrm{D})$, and abundance of aphids (Aphis fabae), indicated that the H. undecimnotata females were in diapause during July and August. The diapause gradually terminated from late August to late October and was followed by a period of quiescence extending from November to March of the following year. During the summer diapause, arrested ovarian development was indicated by the undifferentiated state of the ovaries in all females. Males and females had enlarged fat bodies, and the median preoviposition period after the transfer to the laboratory was 92 days in early July and 64 days in early August. During the winter quiescence, arrested ovarian development was characterized by immature ovaries in females and, in some samples, by vitellogenic resorption in a few females. In winter, adults contained varying amounts of fat body reserves, and the median preoviposition period of females transferred to breeding conditions was 30 days in early November and 16 days in mid January.
\end{abstract}

\section{INTRODUCTION}

Hippodamia undecimnotata is a multivoltine species in Greece. It can complete 5 overlapping generations when reared in outdoor cages and supplied continually with excess of aphid prey (Katsoyannos et al., 1997a). In central Greece, H. undecimnotata reproduces in spring in the lowlands. In June, massive migrations of adults to the summits of nearby mountains are observed. Aggregations are formed and are continually present on the mountains until the beetles begin emigrating, between March and mid April of the following year. From July until the end of October $H$. undecimnotata are scarce in the lowlands and during the winter months, they are absent (Katsoyannos et al., 1997a).

The above observations indicate that $H$. undecimnotata possesses a type of aestivo-hibernation in central Greece. The term "aestivo-hibernation" describes the dormancy that occurs among aphidophagous Coccinellidae in hot, dry temperate and subtropical zones (Hagen, 1962). The following study was conducted to distinguish the types of dormancy H. undecimnotata exhibits in Greece during July-August and from September-January.

\section{MATERIAL AND METHODS}

Samples of 20-40 H. undecimnotata adults were collected once or twice per month during 1991 and 1993 from two locations: the Kopais plain (ca. $38^{\circ} 20^{\prime}-38^{\circ} 30^{\prime}$ N.L.), central Greece, where they were found in the spring on maize, cotton, alfalfa and non-cultivated plants; and their aestivo-hibernation sites on the summit of Mount Chlomo (elevation $1081 \mathrm{~m}$ ) about $40 \mathrm{~km}$ north of Kopais, where they were found from July to February.

The physiological state of the sampled beetles was determined by dissections in Ringer's solution. The development state of the females' ovaries, the contents in the digestive tract and the level of fat body accumulation in adults, were recorded. Female reproductive state is indicated by the presence of either vitellinized oocytes in the ovarioles or signs of vitellogenic resorption in the ovaries. In males, the activity of the follicular tissue in the testes begins at the pupal stage and does not cease in diapausing individuals (Hodek \& Landa, 1971). Therefore, male reproductive state was not considered in this study as a reliable indicator of diapause.

The mid-guts of adults recently fed on aphids are distended and packed with aphid parts. In contrast, the mid-guts of beetles in a state of dormancy are reduced to tubes containing a brown fluid (Mc Mullen, 1967) or are empty (Hodek \& Čerkasov, 1961). Extensive fat body reserves are another conspicuous feature of diapausing coccinellids (Hodek, 1973).

In 1993-1994, batches of $40 \mathrm{H}$. undecimnotata adults were periodically transferred, once or twice per month, from their dormancy sites on Mount Kitheron (elevation 1409 m, about 30 $\mathrm{km}$ to the southeast of Kopais) to the Kifissia laboratory, and reared under constant conditions $\left(25 \pm 1^{\circ} \mathrm{C}\right.$ temperature, $60 \pm 10 \%$ R.H. and 16L : 8D). They were reared in male-female pairs in cylindrical plastic vials $(5.5 \mathrm{~cm}$ in diameter; $6.5 \mathrm{~cm}$ high) and fed an excess of Aphis fabae Scopoli (Hemiptera: Aphididae) reared on Vicia faba L. (Leguminosae) seedlings. The duration of the preoviposition period of each female was recorded.

* Corresponding author; e-mail: dckontodimas@hotmail.com 

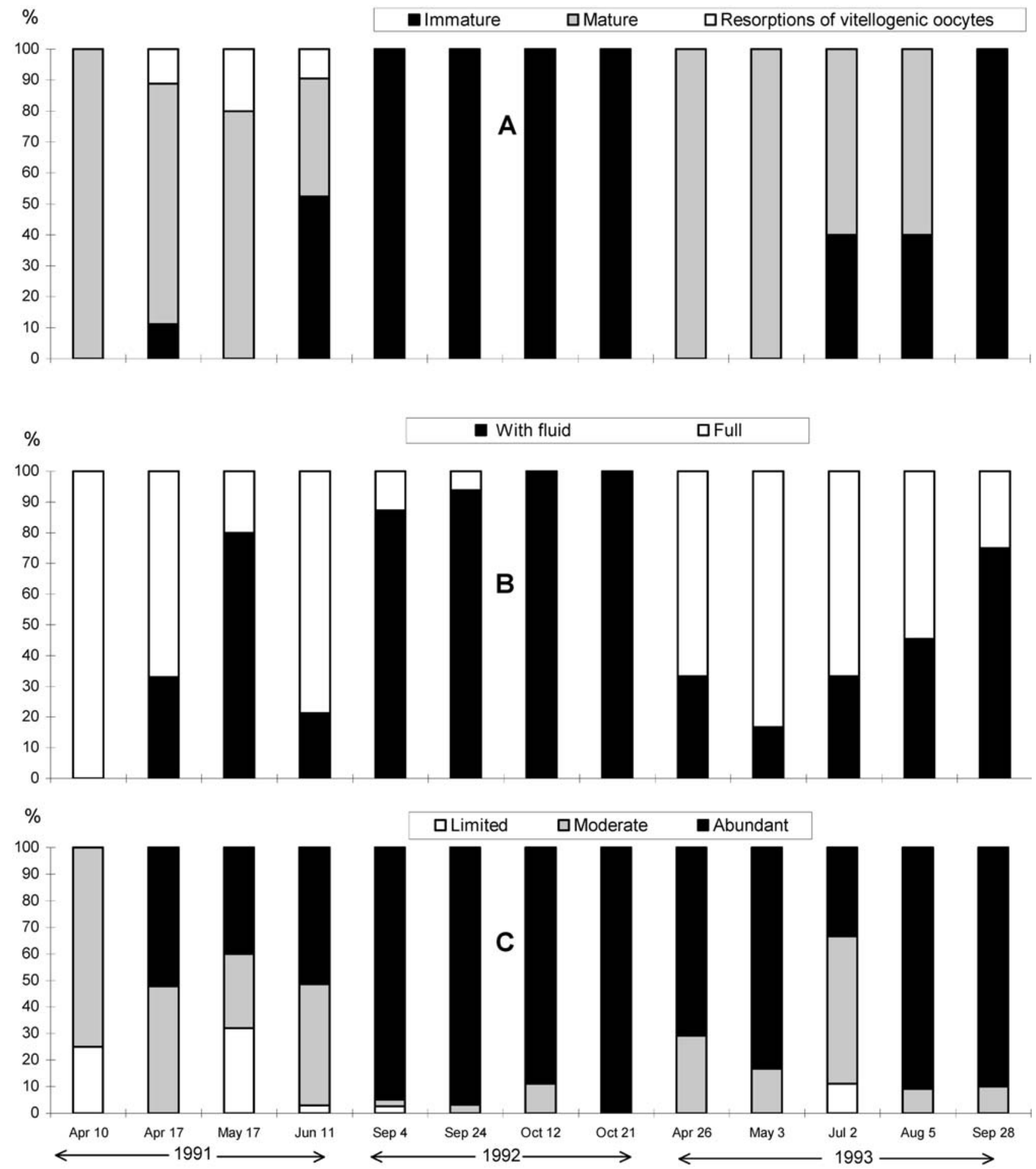

Fig. 1. Dissections of Hippodamia undecimnotata adults collected from the plain of Kopais. A - state of ovaries; B - status of mid-gut; $\mathrm{C}$ - fat body reserves.

\section{RESULTS}

\section{Activity of adults in the lowland area}

During April and May, $>77 \%$ of $H$. undecimnotata females were reproductively mature and active (Fig. 1A), whereas during June, July and August the proportion of females with mature ovaries decreased. During September and October all females contained undifferentiated ovaries (Fig. 1A). Feeding activity during the same period was indicated by the presence of food or fluid in the midguts of the adults (Fig. 1B). The reserves of fat body were moderate (in $16.7-75.0 \%$ of adults) or abundant (in $33.3-83.3 \%$ of adults) during April-June, whereas during August-October, reserves were abundant in $\geq 90.0 \%$ of adults (Fig. 1C). 

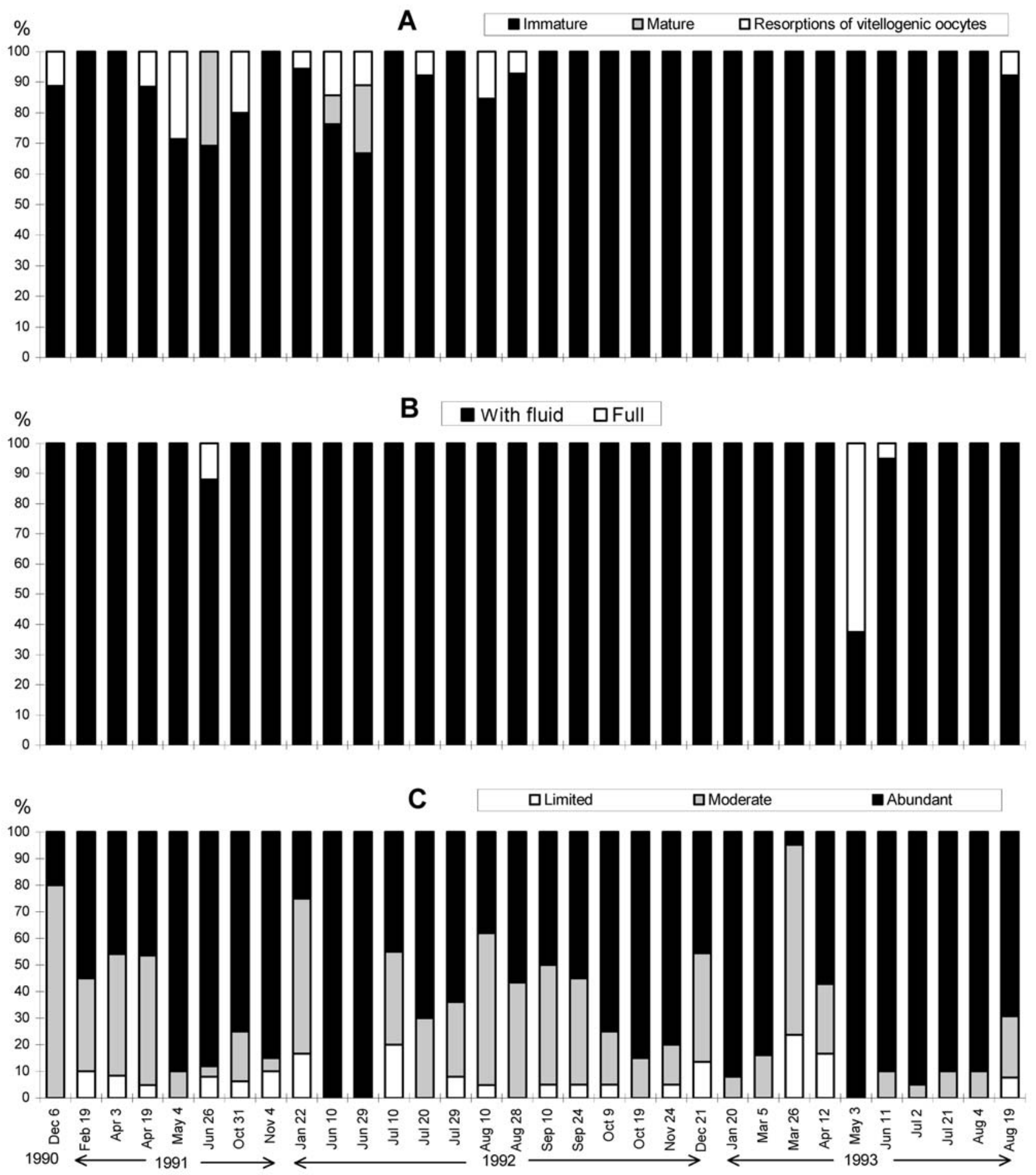

Fig. 2. Dissections of Hippodamia undecimnotata adults collected from the summit of Mount Chlomo (1081 m). A - state of ovaries; $\mathrm{B}$ - status of mid-gut; $\mathrm{C}$ - fat body reserves.

\section{Aestivo-hibernation of adults at the summits of} mountains

\section{The summer diapause}

The greatest proportion of females at the aestivohibernation sites in July and August had immature ovaries, with ovarioles consisting mainly of undifferentiated germaria (Fig.2A). The reduction of contents in the digestive system during the same period was indicated
(Fig. 2B) by the mainly fluid-filled midguts of the adults. In addition, almost all adults dissected during July-August had moderate-to-abundant fat body reserves (Fig. 2C).

A relatively long preoviposition period during the summer months decreases in autumn, as indicated by the values for September-October (Table 1). Particularly, the mean preoviposition period decreased from 94 days in 
TABLE 1. Duration of preoviposition period of females of Hippodamia undecimnotata collected during their aestivo-hibernation from the summit of Mount Kitheron $(1409 \mathrm{~m})$ and transferred to the laboratory $\left(25^{\circ} \mathrm{C}, 16 \mathrm{~L}: 8 \mathrm{D}\right.$, and presence of aphids).

\begin{tabular}{ccccccc}
\hline \multirow{2}{*}{ Collection date } & Females collected & \multicolumn{5}{c}{ Duration of preoviposition (days) } \\
\cline { 3 - 6 } & & Median & Mean & sd & Minimum & Maximum \\
\hline 04-Jul-93 & 16 & 92 & 94 & 4 & 89 & 101 \\
21-Jul-93 & 15 & 68 & 72 & 9 & 68 & 103 \\
04-Aug-93 & 22 & 64 & 64 & 4 & 58 & 68 \\
19-Aug-93 & 20 & 42 & 44 & 6 & 40 & 60 \\
09-Sep-93 & 17 & 21 & 22 & 7 & 11 & 34 \\
28-Sep-93 & 18 & 24 & 30 & 16 & 15 & 66 \\
21-Oct-93 & 19 & 29 & 30 & 6 & 21 & 48 \\
01-Nov-93 & 18 & 30 & 31 & 3 & 28 & 42 \\
18-Nov-93 & 19 & 28 & 29 & 10 & 13 & 46 \\
17-Dec-93 & 20 & 17 & 22 & 10 & 17 & 49 \\
19-Jan-94 & 16 & 16 & 20 & 7 & 12 & 37 \\
30-Mar-94 & 24 & 14 & 15 & 5 & 9 & 29 \\
\hline
\end{tabular}

early July to 64 days during the first week of August. By the middle of August, the preoviposition period was 44 days. From September through March of the following year, the mean preoviposition period ranged between 15 and 31 days.

\section{The winter quiescence}

The preoviposition period of females collected from the summit of Mount Kitheron and transferred to the laboratory in December, January and March was approximately 50 days shorter than the preoviposition period in females collected in July and early August (Table 1).

\section{DISCUSSION}

When reared in outdoor cages in Athens, Greece, Hippodamia undecimnotata completed 5 overlapping generations, but the adults from fields migrate in late June to mountain summits to their aestivo-hibernation sites (Katsoyannos et al., 1997a). In the present study, we observed that $40-52 \%$ of the field collected females contained undifferentiated previtellogenic ovaries in June 1991 and in July and August 1993 (Fig. 1A). In addition, in outdoor cages 29 to $35 \%$ of the females of the $1^{\text {st }}, 2^{\text {nd }}$ and $3^{\text {rd }}$ generation remain immature until August 31, 1994 (Katsoyannos et al., 1997a). This led to the hypothesis that only a portion of the $H$. undecimnotata population reproduces in the lowlands and the remaining adults migrate to the mountain summits and enter summer dormancy. The proportion of the mature females was higher in the outdoor cages possibly because of their prey [young seedlings of Vicia faba (infested by Aphis fabae) or fresh squash (infested by Dysaphis crataegi)] (Rolley et al., 1974; Hodek \& Honěk, 1996). Photoperiod and temperature were the same in the cages and in the field. There is enough aphid prey both in the lowlands at May and June and in the cages. The lack of food in the field in July and August seems not to be related to the induction of summer dormancy in $H$. undecimnotata because during the same period in the outdoor cages, where aphid prey was abundant, dormant adults were observed. In addition, the supply of excess of aphid prey for the dormant adults didn't interrupt their dormancy during summer (Table 3).
The summer dormancy of $H$. undecimnotata in Greece seems to be a long-day and high-temperature induced diapause (Hagen, 1962, Hodek, 1973). This conclusion is supported by data (Fig. 2) showing females with immature ovaries, lack of prey remnants in the digestive system and the presence of abundant fat body reserves in most adults during the summer months. Also, the duration of the preoviposition period of females collected from Mount Kitheron and transferred to the laboratory (Table 1) was much longer in the summer than during the winter. Further evidence is provided by the long duration of preoviposition periods observed during July and August 1994 in portions of the 1st, 2nd and 3rd generation of $H$. undecimnotata females reared from single pairs under field conditions (Katsoyannos et al., 1997a).

The winter dormancy of $H$. undecimnotata in central Greece is probably quiescence. The duration of preoviposition periods in females in winter is less than one-quarter of the duration of equivalent periods noticed in females transferred during the summer diapause (Table 1). Similar results were obtained for $H$. undecimnotata in south-east France where the preoviposition period between mid August and mid October was 16 days on average whereas between mid October and mid January 7-8 days (Iperti \& Hodek, 1976). In addition, the reduction of the proportion of dissected adults with abundant reserves of fat body (Fig. 2) indicates quiescence.

The delay or prevention of oviposition in females by short-day photoperiod, despite favourable temperature and food conditions, was ascertained for $H$. undecimnotata by Hodek \& Iperti (1983). The gradual decline in the preoviposition periods of dormant females that was recorded in the present study, from 94 days at the beginning of July to 44 days in mid August and to 15-31 days between September 9 and March 30, indicates the decrease of intensity of summer diapause and the transition of the population to winter quiescence. The progress of this process is not synchronized in all individuals as demonstrated by the differences between minimum and maximum preoviposition periods during September 1993 - March 1994. Particularly, the minimum preoviposition period was $12-34 \%$ shorter than the maximum during 
July and August, whereas between September and March the minimum was shorter by $33-77 \%$ of the maximum (Table 1).

The assumption that $H$. undecimnotata (as well as Coccinella septempunctata L.) in south-east France aestivate in diapause and hibernate in quiescence, has already been supported by Iperti (1966). Similar results were obtained for the nearctic species Hippodamia convergens in California (USA) (Neuenschwander et al., 1975) and also in central Greece for C. septempunctata (Katsoyannos et al., 1997b) and the scale- and aphid-feeding coccinellid Exochomus quadripustulatus L. (Katsoyannos, 1976).

\section{REFERENCES}

HAGEN K.S. 1962: Biology and ecology of predaceous Coccinellidae. Annu. Rev. Entomol. 7: 289-326.

Hodek I. 1973: Biology of Coccinellidae. Dr Junk Publishers, The Hague and Academia Publishing House of the Czechoslovak Academy of Science, Prague, $260 \mathrm{pp}$.

Hodek I. \& Čerkasov J. 1961: Prevention and artificial induction of imaginal diapause in Coccinella septempunctata L. (Col., Coccinellidae). Entomol. Exp. Appl. 4: 179- 190.

Hodek I. \& HoNĚK A. 1996: Ecology of Coccinellidae. Kluwer Academic Publishers, Dordrecht, 464 pp.

Hodek I. \& IPERTI G. 1983: Sensitivity to photoperiod in relation to diapause in Semiadalia undecimnotata females. Entomol. Exp. Appl. 34: 9-12.

HodeK I. \& LANDA V. 1971: Anatomical and histological changes during dormancy in two Coccinellidae. Entomophaga 16: 239-251.

IPERTI G. 1966: Voltinism and arrest of development in aphidophagous coccinellids of south-east of France. In Hodek I. (ed.): Proceedings of $1^{\text {st }}$ Symposium "Ecology of Aphidophagous Insects", Liblice near Prague, September 27 October 1, 1965. Academia, Prague, pp. 105-106.

IPERTI G. \& HODEK I. 1976: Développement de la diapause chez les femelles de Semiadalia undecimnotata Schn. Ann. Zool. Ecol. Anim. 8: 17-24.

Katsoyannos P. 1976: Etude d'un prédateur: Exochomus quadripustulatus L. (Coleoptera: Coccinellidae) en vue d'une éventuelle utilisation contre: Saissetia oleae (Homoptera: Coccoidea, Coccidae) dans les oliveraies de la Grèce. Thèse Doct. Ingénieur Univ. Sci. et Techn. du Languedoc, Montpellier, France, 144 p.

Katsoyannos P., Kontodimas D.C. \& Stathas G.J. 1997a: Phenology of Hippodamia undecimnotata (Col.: Coccinellidae) in Greece. Entomophaga 42: 283-293.

Katsoyannos P., Kontodimas D.C. \& Stathas G.J. 1997b: Summer diapause and winter quiescence of Coccinella septempunctata (Col.: Coccinellidae) in Greece. Entomophaga 42: 483-491.

McMullen R.D. 1967: A field study of diapause in Coccinella novemnotata (Coleoptera: Coccinellidae). Can. Entomol. 99: 42-49.

Neuenschwander P., Hagen K.S. \& Smith R.F. 1975: Predation on aphids in California's alfalfa fields. Hilgardia 43(2): 53-78.

Rolley F., Hodek I. \& Iperti G. 1974: Influence de la nourriture aphidienne (selon l'âge de la plante-hôte à partir de laquelle les pucerons se multiplient) sur l'induction de la dormance chez Semiadalia undecimnotata Schn. (Coleop., Coccinellidae). Ann. Zool. Ecol. Anim. 6: 53-60.

Received September 9, 2004; revised and accepted June 6, 2005 